\title{
Interaction of host immunity with HER2- targeted treatment and tumor heterogeneity in HER2-positive breast cancer
}

\author{
Gaia Griguolo ${ }^{1,2,3,4}$, Tomás Pascual ${ }^{1,2}$, Maria Vittoria Dieci, ${ }^{3,4}$, Valentina Guarneriं ${ }^{3,4}$ and Aleix Prat ${ }^{1,2^{*}}$
}

\begin{abstract}
Growing evidence suggests a clear role of the host immune system in HER2+ breast cancer. In addition, HER2+ breast cancer is generally considered more immunogenic than hormone receptor-positive (HR+)/HER2-, and specific molecular HER2+ subgroups (e.g. HER2-enriched disease) are more immunogenic than others (e.g. Luminal A or B). From a clinical perspective, the immune system plays a relevant prognostic role in HER2+ breast cancer and contributes to the therapeutic effects of trastuzumab. However, as more HER2-targeted agents become available, a better understanding of the role played by the immune system in modulating therapy response to different agents will be needed. Furthermore, the recent introduction in oncology of immune checkpoint inhibitors capable of unleashing anti-tumor immune response opens new possibilities for therapeutic combinations in HER2+ breast cancer. Here, we review the current pre-clinical and clinical data on the interplay between the immune system and HER2+ breast cancer, focusing on different HER2-targeted treatments and the biological heterogeneity that exists within HER2+ disease. Finally, we discuss new therapeutic approaches exploiting the immune system to increase activity or revert resistance to HER2-targeted agents.
\end{abstract}

Keywords: Breast cancer, HER2, Targeted treatment, Immunity, Tumor infiltrating lymphocytes, Immune checkpoints

\section{Introduction}

HER2 is overexpressed in $15-20 \%$ of breast cancers $(\mathrm{BC})$ and is associated with clinically aggressive disease [1]. Targeting this oncogene has led to striking improvements in survival outcomes for HER2+ BC patients. To date, several HER2-targeted treatments are available, including monoclonal antibodies (trastuzumab, pertuzumab), tyrosine kinase inhibitors (lapatinib, neratinib), and antibody-drug conjugates (Ado-trastuzumab emtansine [T-DM1]) [2-6].

The role of the host immune system in HER2+ BC is becoming an important topic to study for several reasons. First, HER2+ BCs have higher stromal tumor-infiltrating lymphocytes (TILs) levels in general than hormone

\footnotetext{
* Correspondence: alprat@clinic.cat

${ }^{1}$ Translational Genomics and Targeted Therapeutics in Solid Tumors, IDIBAPS, Barcelona, Spain

${ }^{2}$ Department of Medical Oncology, Hospital Clínic, Barcelona, Spain Full list of author information is available at the end of the article
}

receptor positive (HR+)/HER2- BCs, implying that HER2 + disease is usually more immunogenic $[7,8]$. Second, not all HER2+ tumors are immunogenic and specific molecular HER2+ subgroups (e.g. HER2-enriched) are more immunogenic than others (e.g. Luminal A/B) [9]. Third, the percentage of TILs is clinically relevant due to its association with better prognosis $[10,11]$. Fourth, the recent introduction in oncology of therapeutic agents capable of unleashing anti-tumor immune response, such as checkpoint inhibitors, opens new treatment strategies [12]. Finally, the immune system not only plays a prognostic role but also seems to contribute substantially to the therapeutic effects of trastuzumab, originally credited to induce cell death by direct inhibition of HER2 intracellular signaling [13].

To date, several reviews have analyzed the prognostic role of immunity in HER2+ BC and its capability of modulating response to trastuzumab [13]. However, as more HER2-targeted agents have become available in 
recent years, better understanding of the role played by the immune system in modulating response to these new treatments might help optimize or tailor treatment. Furthermore, a deeper understanding of the interaction between immunity and combination of anti-HER2 drugs with hormonotherapy and chemotherapy, in the context of the biological heterogeneity within HER2+ BC, will be required to design biologically meaningful therapy combinations.

\section{HER2 as the antigen}

HER2 overexpression in BC is often described as a typical case of oncogene addiction, thus defining tumors that are almost exclusively dependent on a single oncogenic pathway. As is the case for many oncogenes, its overexpression on the cell membrane and its essential role in tumor cell biology makes it a perfect antigen to guide immune response towards HER2+ cells [14].

In the attempt to induce host immune response towards HER2 for therapeutic uses, vaccines have been designed. A number of HER2-derived peptides have been investigated [15] and some have been shown capable of inducing immune response. However, despite some positive results in phase I-II trials, the development of $\mathrm{BC}$ vaccines has been a story of setbacks and efficacy has not been proved in phase III trials (Additional file 1: Table S1) [16].

On the other hand, host immune response plays a key role in the activity of anti-HER2 monoclonal antibodies.
Indeed, trastuzumab has several mechanisms of action (Fig. 1a). By binding to the extracellular domain of HER2, it prevents receptor dimerization inhibiting downstream signaling. It also increases HER2 internalization and endocytic degradation, thus enhancing HER2 peptide presentation on major histocompatibility complex (MHC) receptors. In addition, while the antibody binds to HER2 on the cell surface, the crystalline fragment $(\mathrm{Fc})$ of the immunoglobulin interacts with Fcgamma-receptors $(\mathrm{F} c \gamma \mathrm{R})$ on innate immune effector cells, like natural killer (NK) cells, neutrophils and $\gamma \delta$ T-cells, activating antibody-dependent cellular cytotoxicity (ADCC) $[17,18]$. This cytolytic activity increases availability of tumor antigens in the tumor microenvironment (TME), favoring antigen presentation. Antigen presentation is also enhanced by Fc $\gamma R$-mediated phagocytosis of immune complexes by antigen-presenting cells. Hence, the interaction between trastuzumab and the innate immune system facilitates the development of tumor-specific T-cell immunity. On one hand, NK-cells prime dendritic cells, enhancing tumor antigen presentation to cytotoxic CD8+ T-cells and polarization of CD4+ T-cells towards an anti-tumor T-helper type 1 (Th1) phenotype. On the other hand, trastuzumab-dependent NK-cell activation leads to cytokine secretion contributing to the recruitment and functional polarization of myeloid and T-cells [19].

Through these mechanisms, anti-HER2 antibodies exert a vaccine-like effect activating the adaptive as well

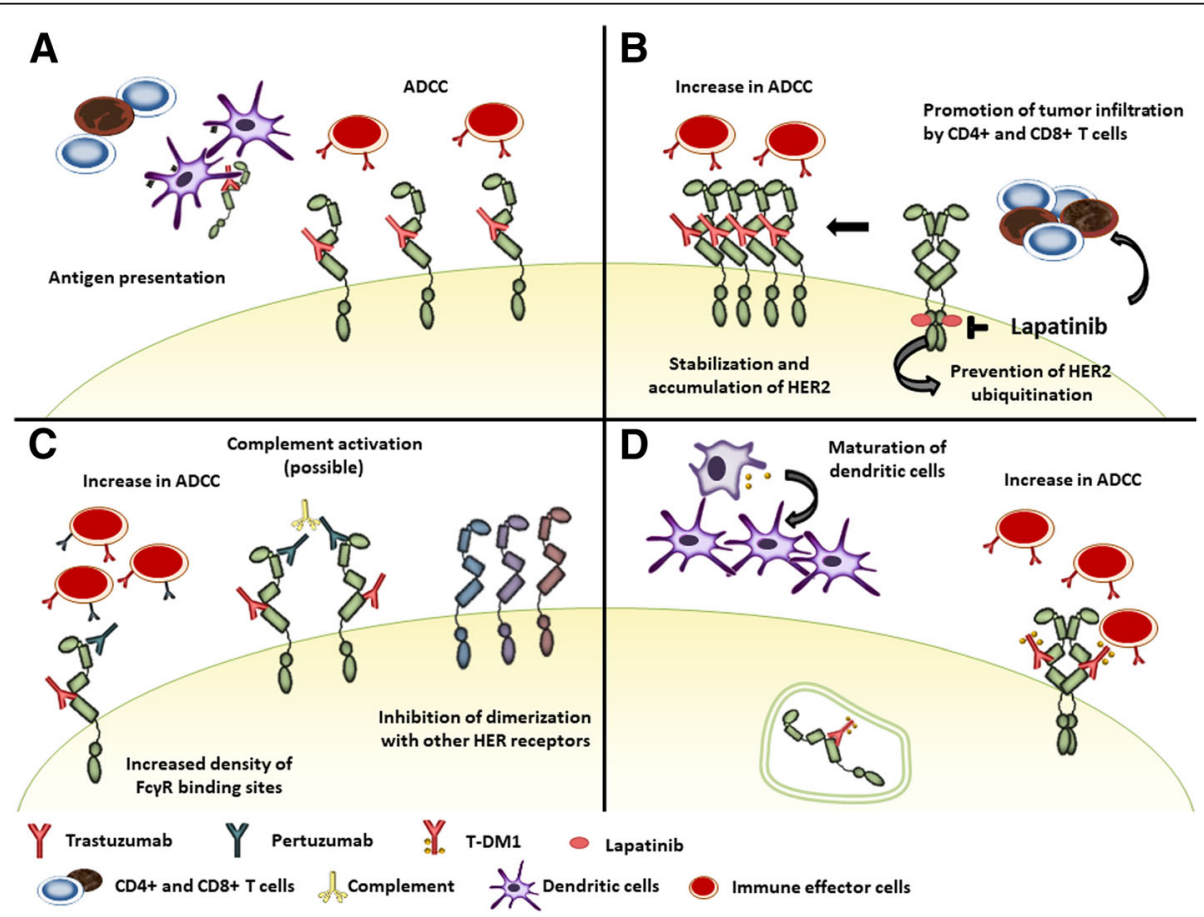

Fig. 1 Immune related mechanisms of action of HER2-targeted agents: trastuzumab (a), lapatinib (b), pertuzumab (c), T-DM1 (d) 
as the innate immune system. Consistently, activation of anti-HER2 CD4+ Th1 response correlates with pathologic complete response (pCR) and disease-free survival (DFS) following anti-HER2 based neoadjuvant chemotherapy $[20,21]$.

\section{Evaluating immunity in BC}

Generally, TILs are typically believed to reflect immunological response; however, they include different cell types usually dominated by T-cells, with variable proportions of B-cells, NK cells, macrophages and dendritic cells. While CD8+, CD4+ Th1 and NK cells are generally considered to favor a tumor-suppressive response, CD4+ T-helper 2 (Th2), FOXP3+ T-regulatory and dendritic cells might play a pro-tumorigenic role [22].

TILs are easily assessed on hematoxylin/eosin stained slides, both in intratumoral and stromal areas (sTILs). Current recommendation is to use sTILs as principal parameter.

However, all mononuclear cells are scored and semi-quantitative evaluation of TILs does not distinguish specific immune cells subtypes. Moreover, no clear cutoff exists to define what is a high infiltrate. Traditionally, the lymphocyte predominant BC (LPBC) definition ( $\geq$ 50-60\% sTILs) has been used. More recently, TILs are measured as a continuous parameter to better represent the continuity of immune response $[22,23]$.

Gene-expression analysis can also be used to infer proportions of infiltrating immune cell populations, providing more information regarding different lymphocyte subpopulations, and to measure immune checkpoint gene expression [24]. Interestingly, checkpoint expression significantly correlates with other immune markers and TILs $[25,26]$.

\section{Host immunity in HER2 + BC treated with chemotherapy and trastuzumab \\ Prognostic role of baseline immunity in early HER2+BC}

To date, most data regarding the clinical validity of pre-existing immune response in HER2+ BC come from patients treated with trastuzumab-based chemotherapy for early BC (Additional file 1: Table S1 and Table S2). From a prognostic perspective, several studies in HER2+ $\mathrm{BC}$ patients receiving neoadjuvant (Table 1 ) or adjuvant [7, 24, 27-30] anti-HER2-based chemotherapy have shown that expression of immune-associated gene signatures and infiltration by TILs in pre-treatment biopsies associated with longer DFS [10], independently of known prognostic clinical-pathological variables.

\section{Role of immunity in residual disease after neoadjuvant treatment}

Timing of TILs evaluation might be important. In residual disease after neoadjuvant therapy, TILs might have a different prognostic meaning. In a retrospective study, including 175 HER2+ BC patients treated with neoadjuvant chemotherapy+/-trastuzumab, sTILs generally decreased during treatment (78\% of patients). Presence of high TILs $(>25 \%)$ in patients with residual disease after neoadjuvant therapy was associated with worse DFS [31]. This pattern is opposite to that reported for triple-negative $\mathrm{BC}$ (TNBC), where high TILs in residual disease associated to better prognosis $[32,33]$. These inconsistencies may be explained by differences in TILs composition across BC subtypes and by changes in TILs composition induced by neoadjuvant antiHER2-containing treatment. A decrease in FOXP3+ TILs has been described in HER2+ tumors achieving $\mathrm{pCR}$, while an increase in FOXP3+ TILs has been described in HER2+ residual disease [34, 35]. Indeed, another study, assessing post-neoadjuvant TILs in 111 HER2 + BC patients treated with chemotherapy+/-trastuzumab, reported that low levels of CD8+ lymphocytes were associated with poor DFS, while low levels of FOXP3 + lymphocytes were associated with better DFS [36].

\section{Predictive role of baseline immunity in early HER2 + BC}

The ability of TILs to predict trastuzumab benefit appears more controversial (Additional file 1: Table S2). In the FINHER trial [29], 232 patients HER2+ BC were randomized to 9 weeks of trastuzumab in addition to adjuvant chemotherapy. In this study, a significant interaction between TILs and trastuzumab survival benefit was observed, suggesting that trastuzumab might be more efficacious in presence of TILs. The NSABP-31 adjuvant trastuzumab trial randomized HER2+ BC patients to receive doxorubicin-cyclophosphamide followed by paclitaxel+/-trastuzumab. It reported similar results when expression of TIL-associated genes was considered, high expression of TIL-associated genes associated with more benefit from trastuzumab (interaction $p=$ 0.03) [28], but did not confirm the interaction between TILs and trastuzumab benefit $(n=1581$, interaction $p=$ 0.556) [30]. Moreover, retrospective analysis of 945 samples from the N9831 trial yield discordant results, as benefit from the addition of trastuzumab was observed in non-LPBC, but not in LPBCs $(n=94$, interaction $p=$ 0.042). However, the number of events in this subgroup was extremely small $(n=8)$. In the same trial, significant benefit from addition of trastuzumab was only observed in immune gene enriched-tumors [24]. The explanation of these discrepancies is currently unknown but might relate to different chemotherapy regimens used in each study, duration of trastuzumab, or concomitant versus sequential trastuzumab administration. Recently, baseline sTILs were assessed in the ShortHER adjuvant trial, which compared 9-weeks versus 1-year trastuzumab in addition to chemotherapy, confirming prognostic value. Moreover, results suggested that low-TILs patients $(<20 \%)$ benefited 
Table 1 Neoadjuvant trials with trastuzumab-containing regimens which assessed the prognostic values of TILs and immune related gene signatures

\begin{tabular}{|c|c|c|c|c|c|}
\hline Study & Treatment & $\begin{array}{l}\text { N. } \\
\text { pts. }^{a}\end{array}$ & Biomarker Tested & $\begin{array}{l}\text { Outcome } \\
\text { Tested }\end{array}$ & Association \\
\hline $\begin{array}{l}\text { CALGB } 40601 \\
\text { [100] } \\
\text { NCT00770809 }\end{array}$ & $\begin{array}{l}P-H \\
P-L \\
P-H L\end{array}$ & 265 & $\begin{array}{l}\text { Immune gene signatures } \\
{[100]}\end{array}$ & $\mathrm{pCR}$ & $\begin{array}{l}\text { IgG signature independently associated with } \mathrm{pCR} \\
\text { at multivariate analysis }\end{array}$ \\
\hline \multirow[t]{3}{*}{$\begin{array}{l}\text { CherLOB [55] } \\
\text { NCT00429299 }\end{array}$} & \multirow{3}{*}{$\begin{array}{l}\mathrm{P}-\mathrm{H} \rightarrow \mathrm{FEC}-\mathrm{H} \\
\mathrm{P}-\mathrm{L} \rightarrow \mathrm{FEC}-\mathrm{L} \\
\mathrm{P}-\mathrm{HL} \rightarrow \mathrm{FEC}-\mathrm{HL}\end{array}$} & \multirow[t]{2}{*}{105} & \multirow[t]{2}{*}{ TILs [55] } & $\mathrm{pCR}$ & $\begin{array}{l}\text { Associated with } \mathrm{pCR} \text { at univariate analyses } \\
\text { (no statistical significance beyond PAM50) }\end{array}$ \\
\hline & & & & EFS & Associated with EFS at univariate analyses \\
\hline & & 86 & $\begin{array}{l}\text { Immune gene signatures } \\
\text { [55] }\end{array}$ & $\mathrm{pCR}$ & $\begin{array}{l}3 \text { out of } 4 \text { signatures maintained association with } \\
\text { pCR after correction for PAM50 }\end{array}$ \\
\hline \multirow{2}{*}{$\begin{array}{l}\text { GeparQuattro } \\
\text { [57] } \\
\text { NCT00288002 }\end{array}$} & \multirow[t]{2}{*}{$\mathrm{EC}-\mathrm{H} \rightarrow \mathrm{D}-\mathrm{H}+/-\mathrm{X}$} & 178 & TILs [57] & $\mathrm{pCR}$ & \\
\hline & & & & & Associated with pCR at multivariate analysis \\
\hline \multirow{2}{*}{$\begin{array}{l}\text { GeparQuinto } \\
\text { [57] } \\
\text { NCT00567554 }\end{array}$} & $\mathrm{EC}-\mathrm{H} \rightarrow \mathrm{D}-\mathrm{H}$ & 162 & \multirow[t]{2}{*}{ TILs [57] } & $\mathrm{pCR}$ & \\
\hline & $E C-L \rightarrow D-L$ & 158 & & $\mathrm{pCR}$ & Not associated with $p C R$ \\
\hline \multirow{2}{*}{$\begin{array}{l}\text { GeparSixto [38] } \\
\text { NCT01426880 }\end{array}$} & \multirow[t]{2}{*}{$\mathrm{PM}-\mathrm{HL}+/-\mathrm{C}$} & 266 & TILs [38] & $\mathrm{pCR}$ & Associated with $\mathrm{pCR}$ at multivariate analyses \\
\hline & & 226 & $\begin{array}{l}\text { mRNA expression of } \\
\text { immunologic genes }\end{array}$ & $\mathrm{pCR}$ & $\begin{array}{l}\text { All } 12 \text { immune mRNA markers were associated with } \\
\text { pCR (10/12 at multivariate analysis) }\end{array}$ \\
\hline \multirow{3}{*}{$\begin{array}{l}\text { NeoALTTO [58] } \\
\text { NCT00553358 }\end{array}$} & \multirow{3}{*}{$\begin{array}{l}\text { P-H } \\
P-L \\
P-H L\end{array}$} & \multirow[t]{2}{*}{387} & \multirow[t]{2}{*}{ TILs [58] } & $\mathrm{pCR}$ & Associated with $\mathrm{pCR}$ at multivariate analysis \\
\hline & & & & EFS & Associated with EFS at multivariate analysis \\
\hline & & 254 & $\begin{array}{l}\text { Immune gene signatures } \\
\text { [59] }\end{array}$ & $\mathrm{pCR}$ & $\begin{array}{l}\text { two T-cell immune signatures were associated with } \\
\text { PCR (only confirmed at multivariate analysis in } \\
\text { P-HL arm) }\end{array}$ \\
\hline \multirow{2}{*}{$\begin{array}{l}\text { NOAH [75] } \\
\text { ISRCTN86043495 }\end{array}$} & $\mathrm{AP} \rightarrow \mathrm{P} \rightarrow \mathrm{CMF}$ & 51 & \multirow{2}{*}{$\begin{array}{l}\text { Four immune metagenes } \\
\text { [45] }\end{array}$} & $\mathrm{pCR}$ & Not associated with pCR \\
\hline & $\mathrm{AP}-\mathrm{H} \rightarrow \mathrm{P}-\mathrm{H} \rightarrow \mathrm{CMF}-\mathrm{H} \rightarrow \mathrm{H}$ & 63 & & $\mathrm{pCR}$ & $3 / 4$ associated with $p C R$ \\
\hline \multirow{3}{*}{$\begin{array}{l}\text { NeoSphere [45] } \\
\text { NCT00545688 }\end{array}$} & \multirow{3}{*}{$\begin{array}{l}\text { DH } \\
\text { DPrtz } \\
\text { DHPrtz } \\
\text { HPrtz }\end{array}$} & 243 & TILs [45] & $\mathrm{pCR}$ & Not significantly associated with $p C R$ \\
\hline & & 305 & PDL1 by IHC [45] & $\mathrm{pCR}$ & Not significantly associated with $p C R$ \\
\hline & & 337 & $\begin{array}{l}\text { Immune genes and } \\
\text { metagenes [45] }\end{array}$ & $\mathrm{pCR}$ & $\begin{array}{l}5 \text { associated with pCR at multivariate analysis } \\
\text { (different results in the DHPrtz arm) }\end{array}$ \\
\hline \multirow{4}{*}{$\begin{array}{l}\text { Tryphaena [44] } \\
\text { NCT00976989 }\end{array}$} & \multirow{4}{*}{$\begin{array}{l}\text { FEC } \rightarrow \text { DHPrtz } \\
\text { FECHPrtz } \rightarrow \text { DHPrtz } \\
\text { CycloDHPrtz }\end{array}$} & \multirow[t]{2}{*}{213} & \multirow[t]{2}{*}{ TILs [43] } & $\mathrm{pCR}$ & Not significantly associated with $p C R$ \\
\hline & & & & EFS & Associated with EFS at multivariate analysis \\
\hline & & \multirow[t]{2}{*}{173} & \multirow[t]{2}{*}{$\begin{array}{l}\text { Immune signatures and } \\
\text { genes [43] }\end{array}$} & $\mathrm{pCR}$ & $\begin{array}{l}2 \text { signatures and } 4 \text { genes associated with } \mathrm{pCR} \text { at } \\
\text { multivariate analysis }\end{array}$ \\
\hline & & & & EFS & Not associated with EFS at multivariate analysis \\
\hline $\begin{array}{l}\text { PAMELA [9] } \\
\text { NCT01973660 }\end{array}$ & $\mathrm{HL}$ & 134 & TILs at day 15 & $\mathrm{pCR}$ & Associated with $\mathrm{pCR}$ at multivariate analysis \\
\hline
\end{tabular}

\footnotetext{
${ }^{a}$ Number of patients included in the biomarker analysis

A doxorubicin, C carboplatin, Cyclo cyclophosphamide, CMF cyclophosphamide-methotrexate-fluorouracil, D docetaxel, EC epirubicin-cyclophosphamide, EFS event-free survival, FEC fluorouracil-epirubicin-cyclophosphamide, $H$ trastuzumab, IHC immunohistochemistry, $L$ lapatinib, $P$ paclitaxel, $p C R$ pathologic complete response, $P M$ weekly paclitaxel + non pegylated liposomal doxorubicin, Prtz pertuzumab, TIL tumor infiltrating lymphocytes, $X$ capecitabine Data from the GeparQuattro trial and from the EC-H $\rightarrow$ D-H arm of the GeparQuinto trial were analyzed jointly
}

particularly from 1-year trastuzumab over 9-weeks, whereas high-TILs patients experienced an excellent outcome irrespectively of trastuzumab duration (interaction $p=0.015$ ) [37].
One important aspect is that TILs might also predict sensitivity to the chemotherapy component. In the Geparsixto trial, 273 HER2+ BC patients received a combination of paclitaxel, anthracycline, trastuzumab, 
lapatinib +/- carboplatin as neoadjuvant treatment. When 266 HER2+ baseline samples were analyzed [38], not only both sTILs as a continuous variable and LPBC were associated with $\mathrm{pCR}$, but both significantly interacted with the addition of carboplatin (LPBCs showing higher $\mathrm{pCR}$ rates when receiving carboplatin). This suggests that TILs might also predict for sensitivity to chemotherapy.

Overall, the current data establishes the clinical validity of pre-existing TILs as a prognostic biomarker. However, more studies are needed to establish the clinical utility of TILs. In early HER2+ BC, several escalation (i.e. adding a second anti-HER2 agent) and de-escalation (i.e. shorter trastuzumab regimens, less-chemotherapy or non-chemotherapy) approaches have been or are being tested. In this context, TILs together with other prognostic clinicopathological variables might allow the construction of prognostic risk models that might help better treat our patients [39].

\section{Host immunity and other HER2-targeted therapies}

Due to their different nature and mechanisms of action, the interaction between immune system and new HER2-targeted treatments might be different from that described with trastuzumab alone (Fig. 1).

\section{Pertuzumab}

Pertuzumab is a monoclonal antibody directed against the extracellular dimerization domain of HER2 (a different epitope than trastuzumab). Its binding inhibits dimerization of HER2 with other receptors of the HER family. As trastuzumab, pertuzumab can mediate ADCC and simultaneous binding of both antibodies to different HER2 epitopes increases the density of $F c \gamma R$ binding sites on HER2+ cells, possibly enhancing NK-mediated ADCC responses [40]. Consistently, studies on mouse models have reported that combining the two antibodies increases the total number of tumor infiltrating NK-cells and the proportion of them actively engaged in killing tumor cells [41]. In addition, only tumor cells treated with the combination are likely to have a sufficient number of cell-bound antibodies to induce efficient C3 opsonization, required to initiate complement-mediatedcytotoxicity and macrophage-mediated tumor cell killing [42]. However, if this might explain the mechanism of action of pertuzumab or if its improved efficacy in combination with trastuzumab only relies on a more profound pathway inhibition [43] is still unclear.

\section{Pertuzumab in the neoadjuvant setting}

As pertuzumab only shows significant activity when used in combination with trastuzumab, separating its immune effect in the clinical setting is almost impossible. In the neoadjuvant setting, pertuzumab has been tested in several trials. In the TRYPHAENA trial, testing neoadjuvant pertuzumab and trastuzumab with multi-agent chemotherapy, TILs confirmed their prognostic role. Every 10\% increase in baseline TILs was associated with a $25 \%$ reduction in DFS hazard, after adjusting for clinicopathological characteristics and pCR. Immune gene-expression signatures were also significantly associated with $\mathrm{pCR}$ at multivariate analysis, but not with DFS [44].

The NEOSPHERE trial is a 4-arm study testing neoadjuvant docetaxel in association with trastuzumab, pertuzumab, both or the combination of the two antibodies without chemotherapy. In this trial, baseline TILs as a continuous variable were not significantly associated with $\mathrm{pCR}$, although this might be due to a non-linear effect, as the low TILs group had, as expected, a significantly lower pCR rate. Interestingly, differences were observed across treatment arms. Patients treated with dual anti-HER2 blockade plus docetaxel showed higher rates of $\mathrm{pCR}$, as compared to other treatment arms, in low and intermediate TILs groups, but not in the LPBC group. The impact of immune activation was also explored using gene expression analysis. In the trastuzumab-docetaxel, pertuzumab-docetaxel and in the chemotherapy-free arm, high expression of PDL1, MHC1, and IF-I metagenes associated with lower pCR rates, while high expression of PD1, STAT1, and MHC2 associated with higher pCR rates in multivariable analyses. However, the impact of immune-related metagenes differed across treatment groups. In tumors with high activation of the immune system, the activity of all treatments tested appeared similar (including the chemotherapy-free arm and docetaxel-trastuzumab-pertuzumab arm), while in tumors with low expression of PD1, CTLA4, and MHC1 the use of docetaxel-trastuzumab-pertuzumab was associated with a 2 to 20 -fold higher likelihood of $\mathrm{pCR}$ as compared to other arms. Indeed, the group in which chemotherapy-trastuzumab performed the least appeared to derive the most benefit from adding pertuzumab [45].

Recently, results from the neoadjuvant PerElisa trial, testing pertuzumab, trastuzumab and letrozole in $\mathrm{HR}$ +/HER2+ BC patients selected using Ki67 response after short-course hormonotherapy, were reported. In this trial, baseline TIL levels did not show any impact on pCR [46]. Whether this might be due to the small number of patients, to enrichment in luminal subtypes, to the combination with hormonotherapy or to the absence of chemotherapy remains unclear.

\section{Pertuzumab in the metastatic setting}

In the metastatic setting, data from the CLEOPATRA trial, testing the addition of pertuzumab to trastuzumabdocetaxel as first-line treatment for HER2+ metastatic 
$\mathrm{BC}(\mathrm{mBC})$, confirmed the positive prognostic role of sTILs. Even if the association between sTILs and progression-free survival (PFS) was not significant, each $10 \%$ increase in sTILs significantly associated with longer overall survival (OS). The prognostic effect of TILS appeared to be stronger for OS than for PFS, while no significant interaction with treatment was reported [11]. Two phase III trials assessing addition of pertuzumab to standard treatment in HER2+ $\mathrm{mBC}$, the CLEOPATRA and PHEREXA trials [3, 47], consistently reported a higher magnitude of benefit in terms of OS than of PFS. Enhancement of anti-tumor immune activity by combination of pertuzumab and trastuzumab has been proposed as a possible mechanism for this delayed treatment benefit. Evocatively, a similar benefit in OS with limited benefit in PFS has been described in trials assessing immune checkpoint inhibitors $[48,49]$.

However, in the CLEOPATRA trial only a small number of patients was pretreated with trastuzumab (10.9\%) and most samples analyzed came from primary tumors (93\%). In fact, while in untreated BC TILs are associated with a T-effector phenotype, allegedly reflecting an effective antitumour response, immunogenicity is supposed to decrease in the metastatic setting due to activation of immune-evasion mechanisms and to treatment-induced modifications of TME [35]. Consistently, a recent study which assessed sTILs in metastatic samples from 51 HER2+ BCs, mostly pretreated with HER2-targeted agents, did not observe any favorable impact of high sTILs on OS; indeed, a not statistically significant inverse relationship between TILs and prognosis was observed [50].

\section{Lapatinib}

Lapatinib is a reversible inhibitor of both HER2 and EGFR intracellular tyrosine kinase domains. Due to its intracellular activity, lapatinib might appear to lack the immune activity classically reported with trastuzumab. However, while trastuzumab mediates downregulation and degradation of HER2, lapatinib inhibits phosphorylation of HER2 tyrosine domain, thus preventing ubiquitination. This induces accumulation of HER2 on the cell membrane [51], increasing trastuzumab-dependent ADCC when administered in combination [52]. Lapatinib can also modulate TME. In animal models lapatinib promotes tumor infiltration by CD4 + CD8 + IFN- $\gamma$-producing T-cells through a Stat1 dependent pathway. Stat1-deficiency reduces therapeutic activity of lapatinib, suggesting that immune activation can play a role in its antitumor activity [53].

Lapatinib in the neoadjuvant setting Lapatinib has been tested in various clinical settings, either alone or in combination with chemotherapy, trastuzumab or hormonotherapy. Recently, a metanalysis of five neoadjuvant trials reported the impact of TILs in HER2+ BC treated with chemotherapy plus trastuzumab, lapatinib or their combination [54]. Four trials used a combined regimen of anthracyclines and taxanes (CherLOB, GeparQuattro, GeparQuinto and GeparSixto [55-57]), while paclitaxel alone was administered in the NeoALTTO trial [58]. In patients receiving anthracyclines and taxanes, high baseline TILs were significantly associated with $\mathrm{pCR}$, irrespective of the anti-HER2 treatment received (interaction $p=0.077$ ). In the NeoALTTO trial, the relationship between TILs and pCR was nonlinear and rates of pCR increased sharply for TIL levels greater than $5 \%(p=$ 0.01 ), regardless of treatment group (interaction $p=$ 0.519) [58]. However, the relationship between TILs and DFS was linear, regardless of treatment group, and patients with high TILs at baseline had better outcomes independently of whether they achieved pCR. Authors suggested anthracyclines given after surgery might explain the linear relationship with event-free survival.

Immune activation gene signatures were also tested in some of these trials. In the NeoALTTO trial, two T-celldriven immune signatures significantly associated with pCR. However, this association was only confirmed in multivariable analysis in the combination arm and a significant interaction between these gene signatures and treatment (combination vs single arms) was reported [59]. In the CHERLOB trial, a T-cell gene signature and two immune-related gene signatures significantly correlated with $\mathrm{pCR}$ in a multivariate model adjusted by PAM50 [55]. Fc $\gamma \mathrm{R}$ polymorphisms (FcyRIIa-H131R, FcyRIIIa-V158F) were also tested: only FcyRIIIa V allele carriers showed significant improvement in $\mathrm{pCR}$ with dual HER2-blockade (trastuzumab-lapatinib-chemotherapy), and a significant interaction between FcyRIIIa V allele and combination treatment was observed [60]. This might hint to a relevant role for ADCC in determining benefit of combining trastuzumab and lapatinib as compared to single agent, consistently with the significant interaction between immune signatures and combination treatment reported in the NeoALTTO trial [59].

Lapatinib in the neoadjuvant setting: Chemo-free combinations A limited number of trials have tested chemotherapy-free combinations of lapatinib and trastuzumab in metastatic and neoadjuvant setting. The neoadjuvant PAMELA trial treated 151 HER2+ BC patients with trastuzumab-lapatinib (and hormonotherapy if HR-positive) [61]. In this trial, only sTILs at day 15 were significantly associated with $\mathrm{pCR}$ at multivariable analysis [9]. 
Lapatinib in the metastatic setting In the metastatic setting, the CCTG MA.31 trial [62], a phase III trial randomizing 652 HER2+ $\mathrm{mBC}$ patients to receive either trastuzumab or lapatinib with taxane, casts an interesting perspective on the role of immunity in modulating activity of HER2-targeted treatment. In this trial, TILs assessed on primary tumor specimens were neither prognostic nor predictive. However, patients with low numbers of CD8+ TILs showed higher risk of progressing when treated with lapatinib compared with trastuzumab (Hazard ratio 2.94; $P=0.003$ ) than patients with high CD8+ TILs (Hazard ratio 1.36; $P=0.02$ ). The differential effect and a significant interaction was confirmed in a multivariable model [62].

Thus, low CD8+ sTILs in primary tumor predict inferior response to lapatinib vs trastuzumab in the metastatic setting. In fact, the immunogenic state of tumors before and after metastasis is possibly different. As immunogenic tumors present better response to neo/adjuvant treatment, we could speculate that most of the metastatic population will be made up by not immunogenic or immune evasive tumors (probably reflected by low CD8+ sTILs). In this group, trastuzumab can still be expected to function through enhancement of ADCC and priming of antitumor-adaptive T-cell responses. Indeed, previous treatment might modify the immune status of tumors and this should be taken into account in future clinical trials.

\section{$T-D M 1$}

T-DM1 is an antibody-drug conjugate formed by trastuzumab linked to the cytotoxic agent DM1. After binding HER2, T-DM1 is internalized, degraded in the endosome, releasing DM1. In addition, T-DM1 blocks HER2 signaling pathway and mediates ADCC.

Antitumor immunity might contribute to T-DM1 therapeutic activity. Ansamitocin P3, the precursor of DM1, induces maturation of dendritic cells, facilitates antigen uptake and migration of tumor-resident dendritic cells to tumor-draining lymph nodes, thereby potentiating antitumor immunity [63, 64]. In a HER2+ mouse model, T-DM1 induced infiltration by effector T-cells, which was essential for its therapeutic activity. After T-DM1 treatment (but not with trastuzumab alone), tumors showed a shift towards a T-cell-inflamed phenotype with an increase in $\gamma \delta \mathrm{T}$-cells and NK-cells and expansion of CD45+. Consistently, the infiltrate showed a strong Th1 immune deviation. In addition, despite the tumor model presented primary resistance to anti-CTLA-4/PD-1 agents, combined use of these agents with T-DM1 resulted in strong antitumor efficacy and in development of immunologic memory [65]. Furthermore, analysis of paired samples from 28 HER2+ $\mathrm{BC}$ patients treated with preoperative T-DM1 showed an increase in number and density of tumor-infiltrating T-cells after treatment [65].

\section{Neratinib}

Neratinib is a pan-HER tyrosine kinase inhibitor. It bonds covalently to a conserved cysteine residue, leading to irreversible inhibition of all four HER receptors, block of downstream pathways and in vitro inhibition of proliferation in tumor cells with trastuzumab resistance [66]. Neratinib recently received approval from FDA and EMA for the extended treatment of early-stage HER2+ $\mathrm{BC}$, based on the phase III ExteNEt trial. This trial reported a small but statistically significant benefit in 5 -year DFS for women receiving neratinib for one year after adjuvant trastuzumab versus placebo $(90.2 \%$ vs $87.7 \%, p=0.009$ ) [6]. Discordantly from what is observed with pertuzumab and lapatinib, $\mathrm{HR}+\mathrm{BC}$ patients appeared to derive greater benefit than HR- patients. It has been suggested that this benefit might rely on intracellular irreversible inhibition of the downstream pathway, potentially limiting crosstalk between the HER2 and endocrine pathways, rendering cells more endocrine-responsive. Despite some evidence suggesting that neratinib can alter HER2 antigen levels, whether this might influence trastuzumab-mediated ADCC remains unknown [67]. Thus, limited available evidence exists regarding the role of immunity in modulating neratinib efficacy.

\section{Anti-HER2 therapy in breast ductal carcinoma in situ (DCIS)}

Anti-HER2 therapy is currently being investigated in DCIS. In a window-of-opportunity trial, patients with HER2-positive DCIS received a single dose of trastuzumab before definitive surgery. No evidence of response was observed. However, trastuzumab augmented NK-cell mediated ADCC, and in one case induced T-cell dependent humoral immunity [68]. A phase III trial of adjuvant trastuzumab in high-risk DCIS (NSABP-43) is currently ongoing to determine if adding trastuzumab to radiotherapy is beneficial in preventing recurrence. Moreover, the effect of tratuzumab on contralateral breast cancer will be evaluated. However, at this time there is no role for routine use of anti-HER2 therapy in DCIS patients.

\section{Looking deeper: Heterogeneity of HER2+ BC and interaction with immune system}

The simplest driver of heterogeneity in HER2+ BC is HR status, differentiating two subgroups with distinct response to HER2-treatment and distinct prognosis. Many immune parameters (i.e. levels of TILs and CD8+ infiltrate) are inversely correlated with HR expression [69], suggesting a reduced immune activity in HR +/HER2+ tumors. In fact, estrogenic signaling interacts 
with immune activity. Estrogen can regulate the transcription of SerpinB9/proteinase inhibitor 9, a granzyme $\mathrm{B}$ inhibitor known to decrease susceptibility of $\mathrm{HR}+\mathrm{BC}$ cells to $\mathrm{NK}$ and CD8+ T-cell cytotoxicity in vitro [70, 71]. Moreover, estrogens might modulate susceptibility of cells to NK-mediated ADCC by upregulating $\mathrm{MHC1}$ transcription [72, 73].

However, HR status does not fully recapitulate heterogeneity in HER2+ BC. In fact, when HER2+ BCs are classified using PAM50 intrinsic subtypes, all subtypes are well represented [61, 74, 75]. The HER2-enriched subtype shows the highest number of mutations $[76,77]$ and is enriched with high frequency of APOBEC3B-associated mutations [78]. APOBEC-mediated mutagenesis is linked to the acquisition of subclonal mutations [79], genomic instability and potential neoantigens expression. This might explain differences observed in immune infiltrate: in neoadjuvant trials (PAMELA and CHERLOB), HER2-enriched tumors showed the highest levels of TILs as compared to other subtypes, especially Luminal A/ B [9, 55]. Luminal and HER2-enriched HER2 + BCs also show genetic differences. The $17 \mathrm{q} 12$ chromosomal region, containing genes encoding chemokines and located proximal to the ERBB2 amplicon, is more frequently coamplified in luminal HER2 + BCs as compared to HER2-enriched HER2+ BCs [80]. Lack of co-amplification, typically observed in HER2-enriched tumors, is associated with higher expression of immune activation and exhaustion-related genes and higher levels of T-cells infiltration [80].

The exceptional sensitivity of HER2-enriched subtype to anti-HER2 treatment, with and without chemotherapy $[61,75]$, might, at least in part, be due to high immune infiltrate. However, while baseline TILs provide additional independent value to intrinsic subtyping in predicting $\mathrm{pCR}$ after neoadjuvant chemotherapy plus HER2-targeted treatment, they have not shown independent predictive value when dual HER2-blockade is used without chemotherapy $[9,46]$.

\section{Looking deeper: Interaction with other cancer therapies}

HER2-targeted agents are mostly administered in combination with other treatments, such as chemotherapy or endocrine therapy. Even though chemotherapy is often considered immunosuppressive, several cytotoxic agents used in $\mathrm{BC}$, including anthracyclines and cyclophosphamide, induce immunogenic cell death, leading to activation of anti-tumor immune responses. Moreover, cyclophosphamide can reduce the number of circulating T-regulatory cells [81]. In addition, it has been suggested that the synergistic effect of taxanes with trastuzumab might be partly explained by an improvement in NK effectiveness, by up-modulation of NK-activator ligands, and enhancement of trastuzumab-mediated
ADCC. Accordingly, NK-cells derived from HER2+ BC patients after taxane-containing therapy expressed higher levels of NKG2D receptor than before [82], suggesting that concomitant administration of taxanes with trastuzumab might maximize the immune effect of the antibody $[63,64]$.

Less is known about immune-modulating effects of hormonotherapy. In preclinical studies, tamoxifen increased HER2 expression in non HER2-amplified BC cell lines, thus increasing NK cell-mediated ADCC. However, in HR+/HER2-amplified cells, tamoxifen failed to improve NK-cell function, probably because the number of HER2 receptors exceeded the number of FcyRIIIa on NK-cells, already maximizing the potential for NK-cell mediated ADCC [83]. In preclinical trials, the aromatase inhibitor anastrozole has been shown to induce immune activation by inhibiting differentiation of naïve T-cells to T-regulatory, increasing pro-inflammatory and reducing anti-inflammatory cytokines levels [84]. Furthermore, immune activation can be enhanced by the combination of hormonotherapy and CDK4/6 inhibitors. In fact, preclinical data has shown that CdK4/6 inhibitors enhance antitumor immunity by increasing antigen presentation and suppressing proliferation of immunosuppressive T-regulatory cells. Consistently, in patients receiving neoadjuvant palbociclib, an enhanced expression of immune-related signatures was observed [85]. However, efficacy of CdK4/6 inhibitors in HER2+ BC is being tested in clinical trials (NCT02947685, NCT02448420) and these agents are not routinely used in the HER2+ subtype [86].

Most of the clinical information we have regarding the interplay between immune system and hormonotherapy is derived from HR+/HER2- BC [87]. In this setting, gene signatures associated with resistance to tamoxifen, both in the advanced and the adjuvant setting, include immune response genes (FCGBP, OTUD7B, WFDC2 in the adjuvant, FCGRT, PSME1, HLA-C, NFATC3 in the advanced setting) [87]. In addition, several inflammation related-genes were identified in gene signatures predictive for poor anti-proliferative response to neoadjuvant aromatase inhibitors [88]. TILs have also been assessed in this context, with discordant results [88, 89].

In a pooled analysis of 3771 patients, baseline TILs as a continuous variable were a predictor of response to neoadjuvant chemotherapy, as evaluated by $\mathrm{pCR}$ rates, in all BC subtypes, including HR+/HER2-. Nonetheless, in contrast with HER2+ and TNBC, in HR+/HER2-BC higher TILs associated with shorter OS at multivariate analysis [10]. It has been speculated that the adverse prognostic effect of TILs might be explained by a relative resistance to hormonotherapy. However, extensive data regarding type of hormonotherapy and quantification of residual disease were not available in this study 
and it cannot be excluded that differences in residual tumor biology might be implicated. For example, in the neoadjuvant chemotherapy GIOB trial, high baseline TILs were associated with a lower rate of Ki67 suppression [89]. Whether a similar effect might be present at least in some subgroups of $\mathrm{HR}+\mathrm{HER} 2+\mathrm{BC}$ remains unknown.

Finally, the hormonal asset of the patient might play, per se, a modulating role on the immune system. Estrogen signaling has been shown to accelerate progression of various estrogen-insensitive tumor models through mobilization of myeloid-derived suppressor cells and enhancement of their immunosuppressive activity, suggesting that anti-estrogenic agents might boost T-cell-dependent antitumor immunity [90]. Menopausal status of patients might therefore potentially play a modulating role, especially in patients not receiving hormonotherapy.

As interest is growing around the use of chemotherapyfree combinations in HER2+ BC, often containing endocrine agents, an accurate assessment of the interplay between immune system and endocrine therapy in $\mathrm{HR}$ $+/$ HER2 + BC is warranted.

\section{Looking forward: Harnessing the immune system in HER2 $+\mathrm{BC}$}

As the contribution of immunity to the activity of HER2-targeted agents has become more apparent, several attempts to exploit it to increase activity or revert resistance to these agents have been made (Table 2).

A first strategy is to optimize ADCC. The interaction between the IgG Fc and the Fc $\gamma R$ on an effector cell is the first step leading to immune cell activation and some common single-nucleotide polymorphisms (SNPs) in Fc $\gamma R$ genes have been associated with different antibody-binding affinities. Even if reported associations of SNPs with response to trastuzumab are discordant [91-93], attempts have been made to enhance antitumor activity through the design of anti-HER2 antibodies engineered for increased affinity for these SNPs. Margetuximab (MGAH22) is a monoclonal antibody which binds the same epitope of HER2 as trastuzumab, with similar affinities and the same anti-proliferative activity. It carries five aminoacid substitutions in the Fc domain to increase binding to low affinity isoforms of $F c \gamma R$ and reduce binding to $\mathrm{CD} 32 \mathrm{~B}$, an inhibitory $\mathrm{FccR}_{\mathrm{C}}$, resulting in superior engagement of effector cells [94]. Phase I trial testing margetuximab single agent in HER2-overexpressing solid tumors reported meaningful clinical activity [94]. Recently, a press release reported that the phase III trial, comparing the addition to chemotherapy of margetuximab vs trastuzumab in HER2+ $\mathrm{mBC}$ patients with progression on prior HER2-targeted treatment, demonstrated a $24 \%$ risk reduction in PFS with margetuximab as compared to trastuzumab. However, complete data is still awaited (NCT02492711).

Immune activation can also be enhanced using bispecific antibodies, capable of targeting both HER2 and T-cells, redirecting immune effector cells to the tumor site. Ertumaxomab is a trifunctional bispecific antibody which targets HER2 and CD3. Despite the strong immunologic responses and initial clinical responses observed in HER2 $+\mathrm{mBC}$, the phase II trial was terminated prematurely due to changes in the company's development plan [95]. Another CD3/HER2 bispecific antibody, GBR 1302, is currently under evaluation in a phase I trial (NCT02829372).

Immunity can also be targeted towards HER2+ cells through HER2 Bi-armed activated T-cells. These T-cells are activated through exposure to murine anti-CD3 monoclonal antibodies and interleukin-2 and then armed with an anti-CD3/anti-HER2 bispecific antibody. This agent was well tolerated in a phase I trial [96] and a phase I/II trial with pembrolizumab is currently ongoing (NCT03272334).

In addition, two phase I/II trials are currently testing autologous HER2 chimeric antigen receptor (CAR)-expressing T-cells in HER2+ $\mathrm{mBC}$ and solid tumor patients (NCT02713984, NCT02547961 completed without results). CARs are genetically engineered hybrid T-cell receptors composed by a single-chain variable fragment ( $\mathrm{scFv}$ ) of the B-cell receptor linked to the T-cell receptor $\mathrm{CD} 3 \zeta$ transmembrane and intracellular signaling domains plus one or more costimulatory domains, which can induce T-cell mediated cytotoxicity in vitro and regression of tumors in mice models [97]. Moreover, another phase I/II trial is ongoing, testing the combination of trastuzumab and NK immunotherapy in relapsed HER $2+B C$ (NCT02843126).

With the coming of age of immunotherapy, the use of checkpoint inhibitors to enhance antitumor immunity in HER2+ $\mathrm{BC}$ has become an attractive strategy. As preclinical evidence suggests that immune-mediated resistance to trastuzumab can be overcome by combination with checkpoint inhibitors [98], several trials have been testing the association of checkpoint inhibitors and HER2-targeted treatment (Table 3). Preliminary results from the phase I/ II PANACEA trial, testing pembrolizumab plus trastuzumab in HER2+ mBC patients who progressed on prior trastuzumab-based therapy, have been presented [12]. In this pretreated population, the combination was active $(15.2 \%$ overall response rate and $24 \%$ clinical benefit rate in the PD-L1+ cohort, no response in the PD-L1- cohort). In the PD-L1+ cohort, baseline sTILs $\geq 5 \%$ were significantly associated with objective response (39\% vs 5\%) and disease control $(47 \%$ vs $5 \%)$. 
Table 2 Active trials testing immune optimized anti-HER2 treatments for HER2+ BC

\begin{tabular}{|c|c|c|c|c|c|}
\hline Strategy Tested & Study & Phase & Setting & Treatment & N. Patients \\
\hline $\begin{array}{l}\text { Immune- } \\
\text { optimized } \\
\text { anti-HER2 } \\
\text { antibodies }\end{array}$ & $\begin{array}{l}\text { SOPHIA } \\
\text { NCT02492711 }\end{array}$ & III & $\begin{array}{l}\text { HER2+ mBC progressed on } \\
\text { HER2-targeted treatment }\end{array}$ & $\begin{array}{l}\text { Randomized: } \\
\text {-Chemotherapy+ Margetuximab } \\
\text {-Chemotherapy+ Trastuzumab }\end{array}$ & 530 (active, not recruiting) \\
\hline $\begin{array}{l}\text { Bispecific } \\
\text { antibodies }\end{array}$ & NCT02829372 & । & $\begin{array}{l}\text { Progressive HER2+ Solid } \\
\text { Tumors }\end{array}$ & GBR1302 (CD3/HER2 bispecific mAb) & 60 (recruiting) \\
\hline \multirow[t]{14}{*}{ Vaccines } & NCT03387553 & । & $\begin{array}{l}\text { During neoadjuvant } \\
\text { treatment (HER2+ BC) }\end{array}$ & HER-2 Pulsed Dendritic cell vaccine & 24 (recruiting) \\
\hline & NCT02061423 & । & $\begin{array}{l}\text { Post-neoadjuvant residual } \\
\text { disease HER-2+ BC }\end{array}$ & HER-2 Pulsed Dendritic cell vaccine & 7 (active, not recruiting) \\
\hline & NCT02063724 & । & $\begin{array}{l}\text { Adjuvant (High Risk HER2+ } \\
\text { BC) }\end{array}$ & HER-2 Pulsed Dendritic cell vaccine & 15 (active, not recruiting) \\
\hline & NCT00436254 & । & Stage III-IV HER2+ BC or OC & $\begin{array}{l}\text { pNGVL3-hICD vaccine (plasmid- } \\
\text { based DNA vaccine) + GM-CSF }\end{array}$ & 66 (active, not recruiting) \\
\hline & NCT01730118 & । & $\begin{array}{l}\text { Solid tumors with 1-3+ } \\
\text { HER2/Neu Expression }\end{array}$ & $\begin{array}{l}\text { Adenoviral Transduced Autologous } \\
\text { HER2/Neu Dendritic Cell Vaccine }\end{array}$ & 65 (recruiting) \\
\hline & NCT01376505 & 1 & Advanced solid tumors & $\begin{array}{l}\text { Synthetic peptides of HER-2 compris- } \\
\text { ing B cell epitopes with a Promiscu- } \\
\text { ous T cell epitope of Measles Virus }\end{array}$ & 36 (recruiting) \\
\hline & NCT01355393 & $|/| \mid$ & Stage II-IV HER2+ BC & $\begin{array}{l}\text { HER-2/neu peptide vaccine + } \\
\text { rintatolimod and/or GM-CSF }\end{array}$ & 50 (active, not recruiting) \\
\hline & NCT00194714 & $|/| \mid$ & $\begin{array}{l}\text { Stage IV HLA-A2+ HER2+ BC } \\
\text { or OC receiving Trastuzumab }\end{array}$ & $\begin{array}{l}\text { HER2 cytotoxic T-cell peptide-based } \\
\text { vaccine }\end{array}$ & $\begin{array}{l}20 \text { (enrolling by } \\
\text { invitation) }\end{array}$ \\
\hline & NCT01922921 & $|/| \mid$ & $\begin{array}{l}\text { Stage IV HER2+ BC receiving } \\
\text { HER2-targeted mAb }\end{array}$ & $\begin{array}{l}\text { Randomized: } \\
\text {-HER2 ICD peptide-based vaccine } \\
\text { +polysaccharide-K } \\
\text {-HER2 ICD peptide-based vaccine } \\
\text { +Placebo }\end{array}$ & 31 (active, not recruiting) \\
\hline & NCT00343109 & $\|$ & $\begin{array}{l}\text { HER2 + stage IIIB- IV BC } \\
\text { receiving trastuzumab }\end{array}$ & $\begin{array}{l}\text { HER-2/neu intracellular domain } \\
\text { peptide-based vaccine mixed with } \\
\text { GM-CSF }\end{array}$ & 38(active, not recruiting) \\
\hline & NCT00266110 & $\|$ & HLA-A0201+ HER2+ mBC & $\begin{array}{l}\text { Dendritic cell Vaccine + GM-CSF + } \\
\text { trastuzumab + vinorelbine }\end{array}$ & 17(active, not recruiting) \\
\hline & NCT03384914 & $\|$ & Adjuvant HER2+ BC & $\begin{array}{l}\text { Randomized: } \\
\text {-Dendritic Cell (DC1) Vaccine } \\
\text {-pUMVC3-IGFBP2-HER2-IGF1R } \\
\text { (WOKVAC) }\end{array}$ & 110 (recruiting) \\
\hline & NCT00640861 & NA & $\begin{array}{l}\text { Treated Stage II/III MUC1+ } \\
\text { HLA-A2+ BC }\end{array}$ & $\begin{array}{l}\text { Randomized: combinations of } \\
\text { MUC1/HER-2/Neu Peptide Based } \\
\text { Immunotherapeutic Vaccines }\end{array}$ & 45 (active, not recruitng) \\
\hline & NCT02297698 & $\|$ & $\begin{array}{l}\text { Adjuvant (High Risk HER2+ } \\
\text { BC) }\end{array}$ & $\begin{array}{l}\text { Randomized: } \\
\text { Trastuzumab/GM-CSF +/- } \\
\text { nelipepimut-S }\end{array}$ & 100 (recruiting) \\
\hline \multirow[t]{2}{*}{$\begin{array}{l}\text { Immune- } \\
\text { stimulating agents } \\
\text { concomitantly } \\
\text { with trastuzumab }\end{array}$} & NCT03571633 & $\|$ & Operable HER2+ BC & $\begin{array}{l}\text { Randomized: } \\
\text { Paclitaxel/trastuzumab +/- } \\
\text { Pegfilgrastim }\end{array}$ & 90 (not yet recruiting) \\
\hline & NCT03112590 & $|/| \mid$ & $\mathrm{HER} 2+\mathrm{BC}$ & $\begin{array}{l}\text { IFN- } \gamma+\text { Paclitaxel+Pertuzumab } \\
+ \text { Trastuzumab }\end{array}$ & 48 (recruiting) \\
\hline \multirow[t]{2}{*}{$\begin{array}{l}\text { Cellular } \\
\text { immunotherapy }\end{array}$} & NCT02843126 & $|/| \mid$ & Recurrent HER2 + BC & $\begin{array}{l}\text { Randomized: } \\
\text { Trastuzumab +/- NK } \\
\text { immunotherapy }\end{array}$ & 30 (recruiting) \\
\hline & NCT02713984 & $|/| \mid$ & $\begin{array}{l}\text { Relapsed or refractory HER2+ } \\
\text { solid tumors }\end{array}$ & anti-HER2 CAR-modified T cells & 60 (recruiting) \\
\hline
\end{tabular}

$B C$ breast cancer, CAR chimeric antigen receptor, GM-CSF granulocyte-macrophage colony-stimulating factor, HLA human leukocyte antigen, ICD intracellular domain, IFN- $\gamma$ interferon gamma, mAb monoclonal antibody, $m B C$ metastatic breast cancer, MUC1 mucin1, $N$ number, NA not available, NK natural killer, $O C$ ovarian cancer 
Table 3 Clinical trials testing the association of checkpoint inhibitors and HER2-targeted treatment in HER2 + BC

\begin{tabular}{|c|c|c|c|c|c|}
\hline Study & Phase & Setting & Treatment & N. Patients & $\begin{array}{l}\text { Primary outcome } \\
\text { evaluated }\end{array}$ \\
\hline $\begin{array}{l}\text { NCT02605915 } \\
\text { Cohort 2A }\end{array}$ & $\mathrm{Ib}$ & $\begin{array}{l}\text { Neoadjuvant } \\
\text { HER2+ BC }\end{array}$ & $\begin{array}{l}\text { Atezolizumab/Trastuzumab/ } \\
\text { Pertuzumab followed by } \\
\text { docetaxel + carboplatin + } \\
\text { trastuzumab + pertuzumab }\end{array}$ & $\begin{array}{l}98 \text { entire trial } \\
\text { (recruiting) }\end{array}$ & Safety \\
\hline $\begin{array}{l}\text { NCT02605915 } \\
\text { Cohort 2B }\end{array}$ & $\mathrm{lb}$ & $\begin{array}{l}\text { Neoadjuvant } \\
\text { HER2+ BC }\end{array}$ & $\begin{array}{l}\text { Atezolizumab }+ \text { T-DM1 followed } \\
\text { by docetaxel }+ \text { carboplatin }+ \\
\text { trastuzumab }+ \text { pertuzumab }\end{array}$ & & \\
\hline $\begin{array}{l}\text { NCT02605915 } \\
\text { Cohort 1A }\end{array}$ & $\mathrm{lb}$ & $\begin{array}{l}\text { locally advanced } \\
\text { or } \mathrm{mHER} 2+\mathrm{BC}\end{array}$ & $\begin{array}{l}\text { Atezolizumab/Trastuzumab/ } \\
\text { Pertuzumab }\end{array}$ & & \\
\hline $\begin{array}{l}\text { NCT02605915 } \\
\text { Cohort 1B-C-D }\end{array}$ & $\mathrm{lb}$ & $\begin{array}{l}\text { locally advanced } \\
\text { or mHER2+ BC }\end{array}$ & Atezolizumab + T-DM1 & & \\
\hline $\begin{array}{l}\text { NCT02605915 } \\
\text { Cohort 1F }\end{array}$ & $\mathrm{lb}$ & $\begin{array}{l}\text { locally advanced } \\
\text { or } \mathrm{mHER} 2+\mathrm{BC}\end{array}$ & $\begin{array}{l}\text { Atezolizumab/Trastuzumab/ } \\
\text { Pertuzumab/ Docetaxel }\end{array}$ & & \\
\hline NCT03032107 & । & mHER2+ BC & T-DM1 + Pembrolizumab & 27 (recruiting) & Safety \\
\hline NCT02649686 & $\mathrm{lb}$ & mHER2+ BC & Trastuzumab + Durvalumab & $\begin{array}{l}15 \text { (active, not } \\
\text { recruiting) }\end{array}$ & Safety \\
\hline NCT03272334 & $|/| \mid$ & $\mathrm{mHER} 2+\mathrm{BC}$ & $\begin{array}{l}\text { Pembrolizumab + Anti-CD3 x } \\
\text { Anti-HER2 Armed Activated T } \\
\text { Cells }\end{array}$ & 33 (recruiting) & Safety \\
\hline $\begin{array}{l}\text { NCT02129556 } \\
\text { (PANACEA) }\end{array}$ & $\mid \mathrm{b} / \mathrm{|l}$ & $\begin{array}{l}\text { Unresectable or } \\
\text { mHER2+ BC }\end{array}$ & Pembrolizumab + Trastuzumab & $\begin{array}{l}58 \text { (active, not } \\
\text { recruiting) }\end{array}$ & $\begin{array}{l}\text { Phase I: Safety } \\
\text { Phase II: Response by } \\
\text { RECIST }\end{array}$ \\
\hline NCT03417544 & $\|$ & $\begin{array}{l}\text { mHER2+ BC with } \\
\text { brain mts }\end{array}$ & $\begin{array}{l}\text { Atezolizumab + trastuzumab }+ \\
\text { pertuzumab }\end{array}$ & 33 (recruiting) & $\begin{array}{l}\text { Overall Response Rate by } \\
\text { RANO-BM criteria }\end{array}$ \\
\hline NCT03125928 & $\|$ & $\begin{array}{l}\text { Unresectable or } \\
\text { mHER2+ BC }\end{array}$ & $\begin{array}{l}\text { Atezolizumab }+ \text { paclitaxel }+ \\
\text { trastuzumab }+ \text { pertuzumab }\end{array}$ & 50 (recruiting) & $\begin{array}{l}\text { Safety and Response by } \\
\text { RECIST }\end{array}$ \\
\hline NCT03414658 & $\|$ & $\begin{array}{l}\text { mHER2 + BC } \\
\text { progressed to } \\
\text { prior trastuzumab } \\
\text { and pertuzumab }\end{array}$ & $\begin{array}{l}\text { Randomized: } \\
\text {-Trastuzumab/Ninorelbine } \\
\text {-Trastuzumab/Ninorelbine } \\
\text { +Avelumab } \\
\text { - Trastuzumab/Vinorelbine } \\
\text { +Avelumab +Utomilumab }\end{array}$ & 100 (recruiting) & PFS \\
\hline NCT03199885 & III & $\mathrm{mHER} 2+\mathrm{BC}$ & $\begin{array}{l}\text { Randomized: } \\
\text {-Paclitaxel/Trastuzumab/ } \\
\text { Pertuzumab + Pembrolizumab } \\
\text {-Paclitaxel/Trastuzumab/ } \\
\text { Pertuzumab }\end{array}$ & $\begin{array}{l}480 \text { (not yet } \\
\text { recruiting) }\end{array}$ & PFS \\
\hline
\end{tabular}

$B C$ breast cancer, $m B C$ metastatic breast cancer, $N$ number, $P F S$ progression-free survival, $R A N O-B M$ response assessment in neuro-oncology - brain metastases

On the other hand, the KATE2 phase II trial failed to demonstrate an overall PFS benefit from adding atezolizumab to T-DM1 in HER2+ mBC. However, a PFS benefit for the combination was present in PD-L1+ and high CD8+ TILs tumors, although the magnitude of benefit was uncertain given the limited number of patients [99].

Several studies testing immune checkpoint inhibitors in combination with HER2-targeted therapies are currently ongoing (Table 3). These will help us understand better the interaction between immune system and HER2-targeted agents and define successful combinations for future clinical trials.

\section{Conclusions}

The role of immunity in cancer treatment has recently moved into the spotlight, as mechanisms related to immune surveillance, immune equilibrium, and immune escape have progressively been elucidated in several solid tumors and new drugs have entered clinical practice. Recent evidence from early phase trials supports the therapeutic role of immunity in HER2 + BC and more data from ongoing trials will be available in the next few years.

In HER2 + BC, the interplay between immune system and tumor is complex and dynamic, involving the interaction with different HER2-targeted treatments, chemotherapy, hormonotherapy and the modulating action of HR status and tumor biology. A deeper understanding of these mechanisms might help optimize treatment personalization in HER2+ BC and design biologically meaningful trials that will eventually change the way we treat patients with HER2+ disease. 


\section{Additional file}

Additional file 1: Table S1. Summary of prognostic/predictive value of tumor infiltrating lymphocytes (TILS) in HER2+ breast cancer across prospective interventional clinical trials. Table S2. Summary of prognostic/predictive value of expression of immune genes and immune gene signatures in HER2+ breast cancer across prospective interventional clinical trials. Table S3. Peptide-based vaccine strategies targeting HER2 for the treatment of invasive HER2+ BC (early and advanced setting). (DOCX $48 \mathrm{~kb}$ )

\section{Acknowledgements}

No additional acknowledgements other than those listed as authors.

\section{Funding}

This work was partly supported by Pas a Pas, Save the Mama, Instituto de Salud Carlos III-PI16/00904 and Career Catalyst Grant CCR13261208 from the Susan Komen Foundation to A.P.

\section{Availability of data and materials}

Not applicable (review article).

\section{Authors' contributions}

GG collected the data and drafted the manuscript. TP, MV and AP revised the manuscript. VG provided additional revisions for the manuscript. All authors read and approved the final manuscript.

\section{Ethics approval and consent to participate}

Not applicable (review article)

\section{Consent for publication}

Not applicable (review article).

\section{Competing interests}

The authors declare that they have no competing interests.

\section{Publisher's Note}

Springer Nature remains neutral with regard to jurisdictional claims in published maps and institutional affiliations.

\section{Author details}

${ }^{1}$ Translational Genomics and Targeted Therapeutics in Solid Tumors, IDIBAPS, Barcelona, Spain. ²Department of Medical Oncology, Hospital Clínic, Barcelona, Spain. ${ }^{3}$ Department of Surgery, Oncology and Gastroenterology, University of Padova, Padova, Italy. ${ }^{4}$ Medical Oncology 2, Istituto Oncologico Veneto IRCCS, Padova, Italy.

Received: 26 September 2018 Accepted: 27 February 2019 Published online: 29 March 2019

\section{References}

1. Slamon D, Clark G, Wong S, Levin W, Ullrich A, McGuire W. Human breast cancer: correlation of relapse and survival with amplification of the HER-2/ neu oncogene. Science. 1987:235:177-82.

2. Balduzzi S, Mantarro S, Guarneri V, Tagliabue L, Pistotti V, Moja L, et al. Trastuzumab-containing regimens for metastatic breast cancer. Cochrane Database Syst Rev. 2014;6:CD006242.

3. Swain SM, Baselga J, Kim SB, Ro J, Semiglazov V, Campone M, et al. Pertuzumab, trastuzumab, and docetaxel in HER2-positive metastatic breast cancer. N Engl J Med. 2015:372:724-34.

4. Verma S, Miles D, Gianni L, Krop IE, Welslau M, Baselga J, et al. Trastuzumab emtansine for HER2-positive advanced breast cancer. N Engl J Med. 2012; 367:1783-91.

5. Geyer CE, Forster J, Lindquist D, Chan S, Romieu CG, Pienkowski T, et al. Lapatinib plus Capecitabine for HER2-positive advanced breast cancer. N Engl J Med. 2006;355:2733-43.

6. Martin M, Holmes FA, Ejlertsen B, Delaloge S, Moy B, Iwata H, et al. Neratinib after trastuzumab-based adjuvant therapy in HER2-positive breast cancer
(ExteNET): 5-year analysis of a randomised, double-blind, placebo-controlled phase 3 trial. Lancet Oncol. 2017:18:1688-700.

7. Loi S, Sirtaine N, Piette F, Salgado R, Viale G, Van Eenoo F, et al. Prognostic and predictive value of tumor-infiltrating lymphocytes in a phase III randomized adjuvant breast cancer trial in node-positive breast cancer comparing the addition of docetaxel to doxorubicin with doxorubicinbased chemotherapy: BIG 02-98. J Clin Oncol. 2013;31:860-7.

8. Stanton SE, Adams S, Disis ML. Variation in the Incidence and Magnitude of Tumor-Infiltrating Lymphocytes in Breast Cancer Subtypes. JAMA Oncol. 2016;2:1354.

9. Nuciforo P, Pascual T, Cortés J, Llombart-Cussac A, Fasani R, Paré L, et al. A predictive model of pathologic response based on tumor cellularity and tumor-infiltrating lymphocytes (CeITIL) in HER2-positive breast cancer treated with chemo-free dual HER2 blockade. Ann Oncol. 2018;29:170-7.

10. Denkert C, von Minckwitz G, Darb-Esfahani S, Lederer B, Heppner Bl, Weber $K E$, et al. Tumour-infiltrating lymphocytes and prognosis in different subtypes of breast cancer: a pooled analysis of 3771 patients treated with neoadjuvant therapy. Lancet Oncol. 2018;19:40-50.

11. Luen SJ, Salgado R, Fox S, Savas P, Eng-Wong J, Clark E, et al. Tumourinfiltrating lymphocytes in advanced HER2-positive breast cancer treated with pertuzumab or placebo in addition to trastuzumab and docetaxel: a retrospective analysis of the CLEOPATRA study. Lancet Oncol. 2017;18:52-62.

12. Loi S, Giobbe-Hurder A, Gombos A, Bachelot T, Hui R, Curigliano G, et al. Abstract GS2-06: Phase Ib/II study evaluating safety and efficacy of pembrolizumab and trastuzumab in patients with trastuzumab-resistant HER2-positive metastatic breast cancer: Results from the PANACEA (IBCSG 45-13/BIG 4-13/KEYNOTE-014) study. Cancer Res. 2018;78:GS2-06.

13. Bianchini $G$, Gianni L. The immune system and response to HER2-targeted treatment in breast cancer. Lancet Oncol. 2014;15:e58-68.

14. Savas P, Caramia F, Teo ZL, Loi S. Oncogene addiction and immunity: clinical implications of tumour infiltrating lymphocytes in breast cancers overexpressing the HER2/neu oncogene. Curr Opin Oncol. 2014;26:562-7

15. Ladjemi MZ, Jacot W, Chardès T, Pèlegrin A, Navarro-Teulon I. Anti-HER2 vaccines: new prospects for breast cancer therapy. Cancer Immunol Immunother. 2010:59:1295-312.

16. Huber CH, Wölfel T. Immunotherapy of cancer: from vision to standard clinical practice. J Cancer Res Clin Oncol. 2004;130:367-74.

17. Molina MA, Codony-Servat J, Albanell J, Rojo F, Arribas J, Baselga J. Trastuzumab (herceptin), a humanized anti-Her2 receptor monoclonal antibody, inhibits basal and activated Her2 ectodomain cleavage in breast cancer cells. Cancer Res. 2001;61:4744-9.

18. Baselga J, Albanell J. Mechanism of action of anti-HER2 monoclonal antibodies. Ann Oncol Off J Eur Soc Med Oncol. 2001;12(Suppl 1):S35-41.

19. Muntasell A, Cabo M, Servitja S, Tusquets I, Martínez-García M, Rovira A, et al. Interplay between Natural killer cells and Anti-HER2 antibodies: Perspectives for breast cancer immunotherapy. Front Immunol. 2017:8:1544

20. Datta J, Berk E, Xu S, Fitzpatrick E, Rosemblit C, Lowenfeld L, et al. Anti-HER2 CD4(+) T-helper type 1 response is a novel immune correlate to pathologic response following neoadjuvant therapy in HER2-positive breast cancer. Breast Cancer Res. 2015:17:71 BioMed Central.

21. Datta J, Fracol M, McMillan MT, Berk E, Xu S, Goodman N, et al. Association of Depressed Anti-HER2 T-Helper Type 1 Response With Recurrence in Patients With Completely Treated HER2-Positive Breast Cancer. JAMA Oncol. 2016;2:242.

22. Hendry S, Salgado R, Gevaert T, Russell PA, John T, Thapa B, et al. Assessing Tumor-infiltrating Lymphocytes in Solid Tumors. Adv Anat Pathol. 2017;24: 235-51.

23. Salgado R, Denkert C, Demaria S, Sirtaine N, Klauschen F, Pruneri G, et al The evaluation of tumor-infiltrating lymphocytes (TILS) in breast cancer: recommendations by an International TILs Working Group 2014. Ann Oncol. 2015;26:259-71.

24. Perez EA, Thompson EA, Ballman KV, Anderson SK, Asmann YW, Kalari KR, et al. Genomic analysis reveals that immune function genes are strongly linked to clinical outcome in the North Central Cancer Treatment Group n9831 Adjuvant Trastuzumab Trial. J Clin Oncol. 2015;33:701-8.

25. Schalper KA, Velcheti V, Carvajal D, Wimberly H, Brown J, Pusztai L, et al. In Situ Tumor PD-L1 mRNA Expression Is Associated with Increased TILs and Better Outcome in Breast Carcinomas. Clin Cancer Res. 2014:20:2773-82.

26. Paré L, Pascual T, Seguí E, Teixidó C, Gonzalez-Cao M, Galván P, et al. Association between PD1 mRNA and response to anti-PD1 monotherapy across multiple cancer types. Ann Oncol. 2018;29:2121-8. 
27. Perez EA, Ballman KV, Tenner KS, Thompson EA, Badve SS, Bailey H. et al., Association of stromal tumor-infiltrating lymphocytes with recurrence-free survival in the $\mathrm{N} 9831$ adjuvant trial in patients with early-stage HER2positive breast cancer. JAMA Oncol. 2016;(1):56-64.

28. Kim S-R, Gavin PG, Pogue-Geile KL, Song N, Finnigan M, Bandos $H$, et al. Abstract 2837: A surrogate gene expression signature of tumor infiltrating lymphocytes (TILs) predicts degree of benefit from trastuzumab added to standard adjuvant chemotherapy in NSABP (NRG) trial B-31 for HER2+ breast cancer. Cancer Res. 2015;75:2837.

29. Loi S, Michiels S, Salgado R, Sirtaine N, Jose V, Fumagalli D, et al. Tumor infiltrating lymphocytes are prognostic in triple negative breast cancer and predictive for trastuzumab benefit in early breast cancer: results from the FinHER trial. Ann Oncol. 2014;25:1544-50.

30. Kim S-R, Song N, Gavin PG, Salgado R, Bandos H, Kos Z. et al. NRG Oncology/NSABP B-31: Stromal tumor infiltrating lymphocytes (sTILs) and outcomes in early-stage HER2-positive breast cancer (BC). 2018 ASCO Annu Meet. J Clin Oncol. 2018;36(suppl; abstr 12010).

31. Hamy A-S, Pierga J-Y, Sabaila A, Laas E, Bonsang-Kitzis H, Laurent C, et al. Stromal lymphocyte infiltration after neoadjuvant chemotherapy is associated with aggressive residual disease and lower disease-free survival in HER2-positive breast cancer. Ann Oncol. 2017;28:2233-40.

32. Dieci MV, Mathieu MC, Guarneri V, Conte P, Delaloge S, Andre F, et al. Prognostic and predictive value of tumor-infiltrating lymphocytes in two phase III randomized adjuvant breast cancer trials. Ann Oncol. 2015;26:1698-704.

33. Loi S, Dushyanthen S, Beavis PA, Salgado R, Denkert C, Savas P, et al. RAS/ MAPK activation is associated with reduced tumor-infiltrating lymphocytes in triple-negative breast cancer: therapeutic cooperation between MEK and PD-1/PD-L1 immune checkpoint inhibitors. Clin Cancer Res. 2016;22(6): 1499-509.

34. Ladoire S, Arnould L, Apetoh L, Coudert B, Martin F, Chauffert B, et al. Pathologic complete response to neoadjuvant chemotherapy of breast carcinoma is associated with the disappearance of tumor-infiltrating foxp3+ regulatory T cells. Clin Cancer Res. 2008;14:2413-20.

35. Force J, Howie LJ, Abbott SE, Bentley R, Marcom PK, Kimmick G, et al. Early stage HER2-positive breast cancers not achieving a pCR From neoadjuvant trastuzumab- or pertuzumab-based regimens have an immunosuppressive phenotype. Clin Breast Cancer. 2018;18(5):410-7.

36. Ladoire S, Mignot G, Dabakuyo S, Arnould L, Apetoh L, Rébé C, et al. In situ immune response after neoadjuvant chemotherapy for breast cancer predicts survival. J Pathol. 2011:224:389-400.

37. Dieci MV, Conte P, Bisagni G, Brandes AA, Frassoldati A, Cavanna L, et al. Association of tumor-infiltrating lymphocytes with distant disease-free survival in the ShortHER randomized adjuvant trial for patients with early HER2+ breast cancer. Ann Oncol. 2019; Epub 17 Jan 2019.

38. Denkert C, von Minckwitz G, Brase JC, Sinn BV, Gade S, Kronenwett R, et al. Tumor-infiltrating lymphocytes and response to neoadjuvant chemotherapy with or without carboplatin in human epidermal growth factor receptor 2positive and triple-negative primary breast cancers. J Clin Oncol. 2015;33: 983-91.

39. Savas P, Salgado R, Denkert C, Sotiriou C, Darcy PK, Smyth MJ, et al. Clinical relevance of host immunity in breast cancer: from TILs to the clinic. Nat Rev Clin Oncol. 2016;13:228-41.

40. Yamashita-Kashima Y, lijima S, Yorozu K, Furugaki K, Kurasawa M, Ohta M, et al. Pertuzumab in combination with trastuzumab shows significantly enhanced antitumor activity in her2-positive human gastric cancer xenograft models. Clin Cancer Res. 2011;17:5060-70.

41. Tóth G, Szöör Á, Simon L, Yarden Y, Szöllősi J, Vereb G. The combination of trastuzumab and pertuzumab administered at approved doses may delay development of trastuzumab resistance by additively enhancing antibody-dependent cell-mediated cytotoxicity. MAbs. 2016;8: $1361-70$.

42. Mamidi S, Cinci M, Hasmann M, Fehring V, Kirschfink M. Lipoplex mediated silencing of membrane regulators (CD46, CD55 and CD59) enhances complement-dependent anti-tumor activity of trastuzumab and pertuzumab. Mol Oncol. 2013;7:580-94.

43. Scheuer W, Friess T, Burtscher H, Bossenmaier B, Endl J, Hasmann M. Strongly Enhanced antitumor activity of trastuzumab and pertuzumab combination treatment on HER2-positive human xenograft tumor models. Cancer Res. 2009;69:9330-6.

44. Ignatiadis M, Van den Eynden G, Roberto S, Fornili M, Bareche $Y$, Desmedt $C$, et al. Tumor-infiltrating lymphocytes in patients receiving trastuzumab/ pertuzumab-based chemotherapy: A TRYPHAENA substudy. JNCI J Natl Cancer Inst. 2019;111(1):69-77.

45. Bianchini G, Pusztai L, Pienkowski T, Im Y-H, Bianchi GV, Tseng L-M, et al. Immune modulation of pathologic complete response after neoadjuvant HER2-directed therapies in the NeoSphere trial. Ann Oncol. 2015;26(12):2429-36.

46. Guarneri V, Dieci M, Bisagni G, Frassoldati A, Bianchi G, De Salvo G, et al. Deescalated treatment with trastuzumab-pertuzumab-letrozole in patients with HR+/HER2+ operable breast cancer with Ki67 response after 2 weeks etrozole: Final results of the PerELISA neoadjuvant study. J Clin Oncol. 2018; 36:abstr 507.

47. Urruticoechea A, Rizwanullah M, Im S-A, Ruiz ACS, Láng I, Tomasello G, et al. Randomized phase III trial of trastuzumab plus capecitabine with or without pertuzumab in patients with human epidermal growth factor receptor 2positive metastatic breast cancer who experienced disease progression during or after trastuzumab-based therapy. J Clin Oncol. 2017;35:3030-8.

48. Motzer RJ, Escudier B, McDermott DF, George S, Hammers HJ, Srinivas S, et al. Nivolumab versus everolimus in advanced renal-cell carcinoma. N Engl J Med. 2015;373:1803-13.

49. Reck M, Rodríguez-Abreu D, Robinson AG, Hui R, Csőszi T, Fülöp A, et al Pembrolizumab versus chemotherapy for PD-L1-positive non-small-cell lung cancer. N Engl J Med. 2016;375:1823-33.

50. Dieci MV, Tsvetkova V, Orvieto E, Piacentini F, Ficarra G, Griguolo G, et al. Immune characterization of breast cancer metastases: prognostic implications. Breast Cancer Res. 2018;20:62.

51. Scaltriti M, Verma C, Guzman M, Jimenez J, Parra JL, Pedersen K, et al. Lapatinib, a HER2 tyrosine kinase inhibitor, induces stabilization and accumulation of HER2 and potentiates trastuzumab-dependent cell cytotoxicity. Oncogene. 2009;28:803-14.

52. Maruyama T, Mimura K, Izawa S, Inoue A, Shiba S, Watanabe M, et al. Lapatinib enhances herceptin-mediated antibody-dependent cellular cytotoxicity by up-regulation of cell surface HER2 expression. Anticancer Res. 2011;31:2999-3005.

53. Hannesdóttir L, Tymoszuk P, Parajuli N, Wasmer M-H, Philipp S, Daschil N, et al. Lapatinib and doxorubicin enhance the Stat1-dependent antitumor immune response. Eur J Immunol. 2013;43:2718-29.

54. Solinas C, Ceppi M, Lambertini M, Scartozzi M, Buisseret L, Garaud S, et al. Tumor-infiltrating lymphocytes in patients with HER2-positive breast cancer treated with neoadjuvant chemotherapy plus trastuzumab, lapatinib or their combination: A meta-analysis of randomized controlled trials. Cancer Treat Rev. 2017:57:8-15

55. Dieci MV, Prat A, Tagliafico E, Paré L, Ficarra G, Bisagni G, et al. Integrated evaluation of PAM50 subtypes and immune modulation of pCR in HER2positive breast cancer patients treated with chemotherapy and HER2targeted agents in the CherLOB trial. Ann Oncol. 2016;27:1867-73.

56. Issa-Nummer Y, Darb-Esfahani S, Loibl S, Kunz G, Nekljudova V, Schrader I, et al. Prospective validation of immunological infiltrate for prediction of response to neoadjuvant chemotherapy in HER2-negative breast cancer--a substudy of the neoadjuvant GeparQuinto trial. PLoS One. 2013;8:e79775.

57. Ingold Heppner B, Untch M, Denkert C, Pfitzner BM, Lederer B, Schmitt W, et al. Tumor-infiltrating lymphocytes: a predictive and prognostic biomarker in neoadjuvant-treated HER2-positive breast cancer. Clin Cancer Res. 2016; 22:5747-54

58. Salgado R, Denkert C, Campbell C, Savas P, Nuciforo P, Aura C, et al. TumorInfiltrating lymphocytes and associations with pathological complete response and event-free survival in HER2-positive early-stage breast cancer treated with lapatinib and trastuzumab. JAMA Oncol. 2015;1:448.

59. Fumagalli $D$, Venet $D$, Ignatiadis $M$, Azim HA, Maetens $M$, Rothé $F$, et al. RNA Sequencing to predict response to neoadjuvant anti-HER2 therapy: A secondary analysis of the NeoALTTO randomized clinical trial. JAMA Oncol. 2016;3:227.

60. Musolino A, Naldi N, Dieci MV, Zanoni D, Rimanti A, Boggiani D, et al. Immunoglobulin $\mathrm{G}$ fragment $C$ receptor polymorphisms and efficacy of preoperative chemotherapy plus trastuzumab and lapatinib in HER2-positive breast cancer. Pharmacogenomics J. 2016;16:472-7.

61. Llombart-Cussac A, Cortés J, Paré L, Galván P, Bermejo B, Martínez N, et al. HER2-enriched subtype as a predictor of pathological complete response following trastuzumab and lapatinib without chemotherapy in early-stage HER2-positive breast cancer (PAMELA): an open-label, single-group, multicentre, phase 2 trial. Lancet Oncol. 2017;18:545-54.

62. Liu S, Chen B, Burugu S, Leung S, Gao D, Virk S, et al. Role of Cytotoxic Tumor-Infiltrating Lymphocytes in Predicting Outcomes in Metastatic HER2Positive Breast Cancer. JAMA Oncol. 2017;3:e172085. 
63. Müller P, Martin K, Theurich S, Schreiner J, Savic S, Terszowski G, et al. Microtubule-depolymerizing agents used in antibody-drug conjugates induce antitumor immunity by stimulation of dendritic cells. Cancer Immunol Res. 2014;2:741-55.

64. Martin K, Müller P, Schreiner J, Prince SS, Lardinois D, Heinzelmann-Schwarz $V A$, et al. The microtubule-depolymerizing agent ansamitocin P3 programs dendritic cells toward enhanced anti-tumor immunity. Cancer Immunol Immunother. 2014;63:925-38.

65. Müller P, Kreuzaler M, Khan T, Thommen DS, Martin K, Glatz K, et al. Trastuzumab emtansine (T-DM1) renders HER2 ${ }^{+}$breast cancer highly susceptible to CTLA-4/PD-1 blockade. Sci Transl Med. 2015;7:315ra188.

66. Canonici A, Gijsen M, Mullooly M, Bennett R, Bouguern N, Pedersen K, et al. Neratinib overcomes trastuzumab resistance in HER2 amplified breast cancer. Oncotarget. 2013;4:1592-605.

67. Collins DM, Gately K, Hughes C, Edwards C, Davies A, Madden SF, et al. Tyrosine kinase inhibitors as modulators of trastuzumab-mediated antibodydependent cell-mediated cytotoxicity in breast cancer cell lines. Cell Immunol. 2017;319:35-42.

68. Kuerer HM, Buzdar AU, Mittendorf EA, Esteva FJ, Lucci A, Vence LM, et al. Biologic and immunologic effects of preoperative trastuzumab for ductal carcinoma in situ of the breast. Cancer. 2011;117:39-47.

69. Chung YR, Kim HJ, Jang MH, Park SY. Prognostic value of tumor infiltrating lymphocyte subsets in breast cancer depends on hormone receptor status. Breast Cancer Res Treat. 2017;161:409-20.

70. Kanamori H, Krieg S, Mao C, Di Pippo VA, Wang S, Zajchowski DA, et al. Proteinase Inhibitor 9, an Inhibitor of Granzyme B-mediated Apoptosis, Is a Primary Estrogen-inducible Gene in Human Liver Cells. J Biol Chem. 2000; 275:5867-73.

71. Jiang X, Ellison SJ, Alarid ET, Shapiro DJ. Interplay between the levels of estrogen and estrogen receptor controls the level of the granzyme inhibitor, proteinase inhibitor 9 and susceptibility to immune surveillance by natural killer cells. Oncogene. 2007;26:4106-14

72. Hamada K, Gleason SL, Levi BZ, Hirschfeld S, Appella E, Ozato K. H-2RIIBP, a member of the nuclear hormone receptor superfamily that binds to both the regulatory element of major histocompatibility class I genes and the estrogen response element. Proc Natl Acad Sci. 1989;86:8289-93.

73. Sim BC, Hui KM. A HLA class Icis-regulatory element whose activity can be modulated by hormones. Int J Cancer. 1994;59:646-54.

74. Cejalvo JM, Pascual T, Fernández-Martínez A, Brasó-Maristany F, Gomis RR, Perou CM, et al. Clinical implications of the non-luminal intrinsic subtypes in hormone receptor-positive breast cancer. Cancer Treat Rev. 2018;67:63-70.

75. Prat A, Bianchini G, Thomas M, Belousov A, Cheang MCU, Koehler A, et al. Research-based PAM50 subtype predictor identifies higher responses and improved survival outcomes in HER2-positive breast cancer in the NOAH study. Clin Cancer Res. 2014;20:511-21.

76. Koboldt DC, Fulton RS, McLellan MD, Schmidt H, Kalicki-Veizer J, McMichael JF, et al. Comprehensive molecular portraits of human breast tumours. Nature. 2012;490:61-70.

77. Perou CM, Sørlie T, Eisen MB, van de Rijn M, Jeffrey SS, Rees CA, et al. Molecular portraits of human breast tumours. Nature. 2000;406:747-52.

78. Roberts SA, Lawrence MS, Klimczak $\amalg$, Grimm SA, Fargo D, Stojanov P, et al. An APOBEC cytidine deaminase mutagenesis pattern is widespread in human cancers. Nat Genet. 2013:45:970-6.

79. Venkatesan S, Rosenthal R, Kanu N, McGranahan N, Bartek J, Quezada SA, et al. Perspective: APOBEC mutagenesis in drug resistance and immune escape in HIV and cancer evolution. Ann Oncol. 2018;29:563-72.

80. Gil Del Alcazar CR, Huh SJ, Ekram MB, Trinh A, Liu LL, Beca F, et al. Immune escape in breast cancer during in situ to invasive carcinoma transition. Cancer Discov. 2017;7:1098-115.

81. Harris SJ, Brown J, Lopez J, Yap TA. Immuno-oncology combinations: raising the tail of the survival curve. Cancer Biol Med. 2016;13:171-93.

82. Di Modica M, Sfondrini L, Regondi V, Varchetta S, Oliviero B, Mariani G, et al. Taxanes enhance trastuzumab-mediated ADCC on tumor cells through NKG2D-mediated NK cell recognition. Oncotarget. 2016;7:255-65.

83. Richards JO, Albers AJ, Smith TS, Tjoe JA. NK cell-mediated antibodydependent cellular cytotoxicity is enhanced by tamoxifen in HER2/neu nonamplified, but not HER2/neu-amplified, breast cancer cells. Cancer Immunol Immunother. 2016;65:1325-35.

84. Wang J, Zhang Q, Jin S, Feng M, Kang X, Zhao S, et al. Immoderate inhibition of estrogen by anastrozole enhances the severity of experimental polyarthritis. Exp Gerontol. 2009;44(6-7):398-405.
85. Goel S, DeCristo MJ, Watt AC, BrinJones H, Sceneay J, Li BB, et al. CDK4/6 inhibition triggers anti-tumour immunity. Nature. 2017;548(7668):471-5.

86. Ciruelos E, Villagrasa P, Paré L, Oliveira M, de la Peña L, Pernas S, et al. Abstract P5-20-19: PAM50 intrinsic subtype predicts survival outcome in HER2-positive/hormone receptor-positive metastatic breast cancer treated with palbociclib and trastuzumab: a correlative analysis of the PATRICIA (SOLTI 13-03) trial. AACR; 2018.

87. Dieci MW, Griguolo G, Miglietta F, Guarneri V. The immune system and hormone-receptor positive breast cancer: Is it really a dead end? Cancer Treat Rev. 2016;46:9-19.

88. Dunbier AK, Ghazoui Z, Anderson H, Salter J, Nerurkar A, Osin P, et al. Molecular profiling of aromatase inhibitor-treated postmenopausal breast tumors identifies immune-related correlates of resistance. Clin Cancer Res. 2013;19:2775-86.

89. Dieci MV, Frassoldati A, Generali D, Bisagni G, Piacentini F, Cavanna L, et al. Tumor-infiltrating lymphocytes and molecular response after neoadjuvant therapy for HR+/HER2 - breast cancer: results from two prospective trials. Breast Cancer Res Treat. 2017;163.

90. Svoronos N, Perales-Puchalt A, Allegrezza MJ, Rutkowski MR, Payne KK, Tesone AJ, et al. Tumor cell-independent estrogen signaling drives disease progression through mobilization of myeloid-derived suppressor cells. Cancer Discov. 2017:7:72-85.

91. Musolino A, Naldi N, Bortesi B, Pezzuolo D, Capelletti M, Missale G, et al. Immunoglobulin $\mathrm{G}$ fragment $\mathrm{C}$ receptor polymorphisms and clinical efficacy of trastuzumab-based therapy in patients with HER-2/ neu -positive metastatic breast cancer. J Clin Oncol. 2008;26:1789-96.

92. Hurvitz SA, Betting DJ, Stern HM, Quinaux E, Stinson J, Seshagiri S, et al. Analysis of Fc receptor Illa and Ila polymorphisms: lack of correlation with outcome in trastuzumab-treated breast cancer patients. Clin Cancer Res. 2012;18:3478-86.

93. Gavin PG, Song N, Kim SR, Lipchik C, Johnson NL, Bandos H, et al. Association of Polymorphisms in FCGR2A and FCGR3A With Degree of Trastuzumab Benefit in the Adjuvant Treatment of ERBB2/HER2-Positive Breast Cancer. JAMA Oncol. 2017;3:335.

94. Bang YJ, Giaccone G, Im SA, Oh DY, Bauer TM, Nordstrom JL, et al. First-inhuman Phase 1 study of margetuximab (MGAH22), an Fc-modified chimeric monoclonal antibody, in patients with HER2-positive advanced solid tumors. Ann Oncol. 2017;28:mdx002.

95. Kiewe $P$, Hasmüller S, Kahlert S, Heinrigs M, Rack B, Marmé A, et al. Phase I trial of the trifunctional anti-HER2 $\times$ Anti-CD3 antibody ertumaxomab in metastatic breast cancer. Clin Cancer Res. 2006;12:3085-91.

96. Lum LG, Thakur A, Al-Kadhimi Z, Colvin GA, Cummings FJ, Legare RD, et al. Targeted T-cell Therapy in Stage IV Breast Cancer: A Phase I Clinical Trial. Clin Cancer Res. 2015;21:2305-14.

97. Li J, Li W, Huang K, Zhang Y, Kupfer G, Zhao Q. Chimeric antigen receptor T cell (CAR-T) immunotherapy for solid tumors: lessons learned and strategies for moving forward. J Hematol Oncol. 2018;11:22.

98. Stagg J, Loi S, Divisekera U, Ngiow SF, Duret H, Yagita H, et al. Anti-ErbB-2 $\mathrm{mAb}$ therapy requires type I and II interferons and synergizes with anti-PD-1 or anti-CD137 mAb therapy. Proc Natl Acad Sci. 2011;108:7142-7.

99. Emens LA, Esteva F, Beresford M, Saura C, De Laurentiis M, Kim S-B, et al. Abstract PD3-01: Results from KATE2, a randomized phase 2 study of atezolizumab (atezo)+trastuzumab emtansine (T-DM1) vs placebo (pbo)+TDM1 in previously treated HER2+ advanced breast cancer (BC). SABCS; 2018

100. Carey LA, Berry DA, Cirrincione CT, Barry WT, Pitcher BN, Harris LN, et al. Molecular Heterogeneity and Response to Neoadjuvant Human Epidermal growth factor receptor 2 targeting in CALGB 40601, a randomized phase III trial of paclitaxel plus trastuzumab with or without lapatinib. J Clin Oncol. 2016:34(6):542-9. 